\title{
Giant pituitary adenoma
}

\author{
Rodrigo Nazário Leão, ${ }^{1}$ José Tiago Baptista, ${ }^{2}$ José Vaz Ribeiro ${ }^{1}$
}

${ }^{1}$ Department of Internal Medicine, Centro Hospitalar Lisboa Central, EPE, Lisboa, Portugal

${ }^{2}$ Department of Neuroradiology, Centro Hospitalar Lisboa Central, EPE, Lisboa, Portugal

\section{Correspondence to} Dr Rodrigo Nazário Leão, rodrigoromaoleao@gmail.com

Accepted 18 October 2014
CrossMark

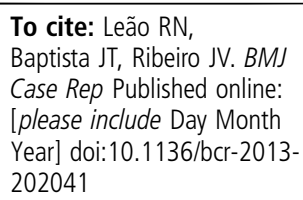

\section{DESCRIPTION}

A healthy 68-year-old man presented in the emergency room with a sudden episode of headache and vomiting together with disequilibrium and crural paresis. The laboratory evaluation revealed hyponatraemia $(\mathrm{Na}+115 \mathrm{mEq} / \mathrm{L})$. Head MRI demonstrated a giant $40 \times 25 \times 31 \mathrm{~mm}$ pituitary lesion (figures 1 and 2). Laboratory studies revealed growth hormone $(\mathrm{GH}) \quad 0.1 \mathrm{ng} / \mathrm{mL} \quad(0.06-5)$, follicle-stimulating hormone (FSH) $14.5 \mathrm{mUI} / \mathrm{mL}$ (0.7-11.1), luteinising hormone (LH) $1.9 \mathrm{mUI} / \mathrm{mL}$ $(0.8-7.6)$, prolactin $23.1 \mathrm{ng} / \mathrm{mL}(2.5-17)$, low free thyroxine (fT4) $0.4 \mathrm{ng} / \mathrm{mL} \quad(0.8-1.9)$, thyroidstimulating hormone (TSH) $7.88 \mathrm{mUI} / \mathrm{mL}(0.4-4)$, cortisol $2.4 \mu \mathrm{g} / \mathrm{dL} \quad(5-25)$, adrenocorticotropic hormone (ACTH) $9.26 \mathrm{pg} / \mathrm{mL}(<46)$, insulin-like growth factor-1 (IGF1) $<25 \mathrm{ng} / \mathrm{mL}(69-200)$, testosterone $<0.04 \mathrm{ng} / \mathrm{mL}(5.6-19)$ and sex hormone binding globulin (SHBG) $30 \mathrm{nmol} / \mathrm{L}$ (13-71).

The cerebral lesion was surgically removed by a trans-sphenoidal approach and the histopathological evaluation has revealed pituitary adenoma (PA) producing gonadotropic hormones (figures 3-5).

Currently, the patient is completely recovered. At the third month postsurgery, laboratory studies revealed GH, FSH, LH, cortisol, ACTH, IGF1, testosterone and SHBG were normal; TSH $4.3 \mathrm{mUI} /$ $\mathrm{mL}$, fT4 $0.6 \mathrm{ng} / \mathrm{mL}$.

The patient is currently under medical treatment with levothyroxine $(100 \mu \mathrm{g} /$ day $)$ without other hormonal replacement therapies. Also, due to the risk

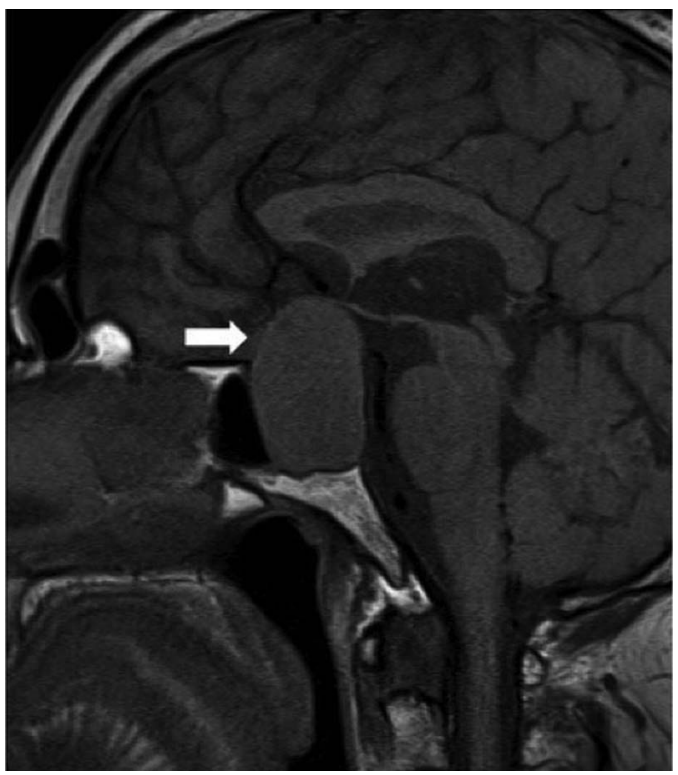

Figure 1 MRI Sagittal T1-weighted image showing a sellar and suprasellar tumour, remodelling the sella turcica. Note the extension of the tumour to the sphenoid sinus. of removing normal functioning pituitary tissue, he was started on corticosteroid treatment in the preoperative period during the first month.

A subsequent head MRI is scheduled for the sixth postsurgical month, to assess any eventual residual adenoma.

The PA is a benign tumour diagnosed in 15-20 million individuals a year. It is responsible for $10-15 \%$ of intracranial tumours. PA is classified as a macroadenoma if it has a diameter of $\geq 10 \mathrm{~mm}$ and as a giant adenoma if the diameter is $\geq 40 \mathrm{~mm}$. Symptoms depend on the size, mass effect and hormonal dysfunction. ${ }^{1}$

Gonadotropic adenomas comprise $10 \%$ of PAs and are generally defined as non-functioning adenomas. Symptoms and signs are usually related with mass effect requiring high clinical suspicion for an early diagnose. The most common symptom is impaired vision (caused by compression of optic chiasm). However, its onset is gradual. In this particular case, despite the size of the adenoma and compression of the optic chiasm, the patient did not have any visual deficit.

In some cases, as in ours, endocrine testing reveals hyperprolactinaemia, ${ }^{2}$ which is due to compression of the pituitary stalk. The majority of the cases present hypopituitarism caused by the compression of normal pituitary cells. Generally, the levels of gonadotropins are low, ending up in



Figure 2 MRI Coronal T2-weighted image illustrates the heterogeneous MR signal evolution. Note the mass effect and compression over the optic chiasm and the deviation of the vascular arcade (both A1 segments of the anterior cerebral arteries and anterior communicating artery). 




Figure 3 Histology of the pituitary adenoma. Tumour with solid and diffuse pattern, consisting of monomorphic, round and cohesive cells without atypia or mitotic activity (H\&E stain).

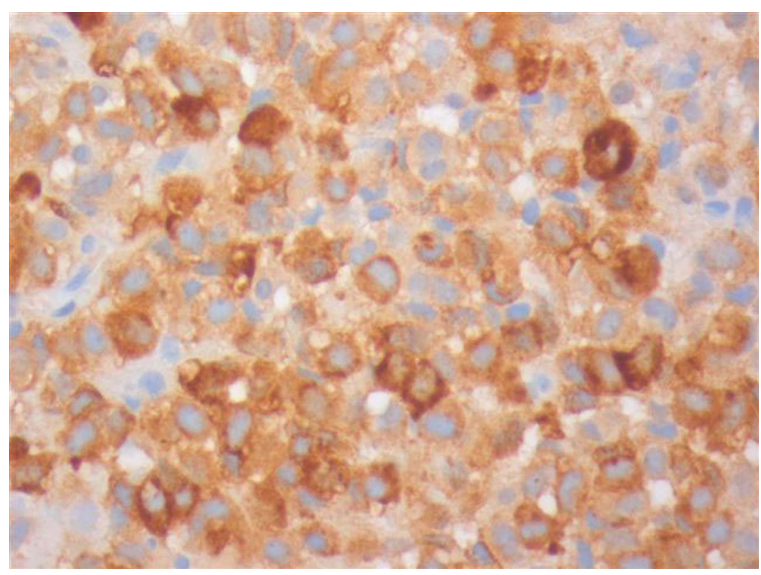

Figure 4 Pituitary adenoma with immunoreactivity for follicle-stimulating hormone (FSH) (FSH-immunohistochemistry stain).

clinical hypogonadism. In this particular case the initial study has revealed low levels of testosterone. Nevertheless, the patient did not report about any decreased libido or erectile dysfunction. His testosterone levels have returned to normal value after surgery.

The most sensitive image method for evaluating pituitary tumours is MRI. It allow clinicians to distinguish PAs from other conditions such as craniopharyngiomas or meningiomas. ${ }^{3}$

Surgery remains the primary option and the trans-sphenoidal approach method is the most popular technique. Radiation therapy (RT) is useful to prevent the regrowth of residual

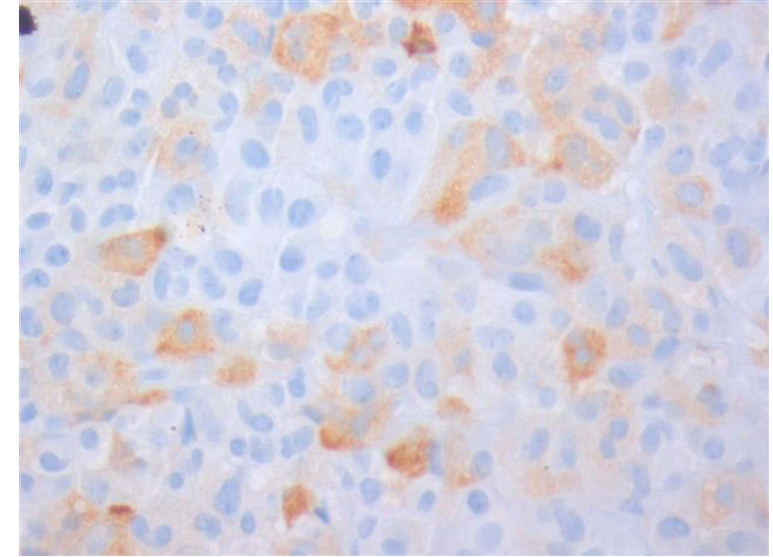

Figure 5 Pituitary adenoma with immunoreactivity for luteinising hormone (LH) (LH-immunohistochemistry stain).

adenomas following trans-sphenoidal surgery. The decision to initiate RT depends on the amount and localisation of residual tissue. $^{13}$

Whatever treatment is used, lifetime re-evaluation by endocrinology and neurosurgery is needed due to the risk of recurrence.

\section{Learning points}

- Lesion mass effect and hormonal dysfunction determine the initial presentation of pituitary macroadenomas.

- Surgery remains the treatment of choice.

- Histopathological study with immunostaining is important to confirm the diagnosis and to define medical therapy.

Acknowledgements The authors would like to express their deepest appreciation to Dr Manuela Mafra who provided and commented on the histology and immunohistochemistry pictures.

Competing interests None.

Patient consent Obtained.

Provenance and peer review Not commissioned; externally peer reviewed.

\section{REFERENCES}

1 Melmed S. Pathogenesis of pituitary tumors. Nat Rev Endocrinol 2011;7:257-66

2 Greenman Y, Stern N. Non-functioning pituitary adenomas. Best Pract Res Clin Endocrinol Metab 2009;23:625-38.

3 McCutcheon IE. Pituitary adenomas: surgery and radiotherapy in the age of molecular diagnostics and pathology. Curr Probl Cancer 2013;37:6-37.

Copyright 2014 BMJ Publishing Group. All rights reserved. For permission to reuse any of this content visit

http://group.bmj.com/group/rights-licensing/permissions.

BMJ Case Report Fellows may re-use this article for personal use and teaching without any further permission.

Become a Fellow of BMJ Case Reports today and you can:

- Submit as many cases as you like

- Enjoy fast sympathetic peer review and rapid publication of accepted articles

- Access all the published articles

- Re-use any of the published material for personal use and teaching without further permission

For information on Institutional Fellowships contact consortiasales@bmjgroup.com

Visit casereports.bmj.com for more articles like this and to become a Fellow 